\title{
Cytotoxicity of Alpinia galanga Rhizome Crude Extract on NIH-3T3 Cells
}

\author{
Ferry Sandra ${ }^{1,2,3}$, Janti Sudiono ${ }^{4}$, Pretty Trisfilha ${ }^{4}$, Deviyanti Pratiwi ${ }^{5}$ \\ ${ }^{1}$ Department of Biochemistry and Molecular Biology, Division of Oral Biology, Faculty of Dentistry, Trisakti University, Jl. Kyai Tapa No.260, \\ Jakarta, Indonesia \\ ${ }^{2}$ Doctoral Program in Medical Science, Faculty of Medicine, University of Sumatera Utara, Jl. Dr. Mansyur No. 9, Medan, Indonesia \\ ${ }^{3}$ BioCORE Laboratory, Faculty of Dentistry, Trisakti University, Jl. Kyai Tapa No.260, Jakarta, Indonesia \\ ${ }^{4}$ Department of Oral Pathology, Division of Oral Biology, Faculty of Dentistry, Trisakti University, J1. Kyai Tapa No.260, Jakarta, Indonesia \\ ${ }^{5}$ Department of Dental Material, Faculty of Dentistry, Trisakti University, Jl. Kyai Tapa No.260, Jakarta, Indonesia \\ *Corresponding author. E-mail: ferrysandra@gmail.com
}

Received date: May 24, 2016; Revised date: Aug 10, 2016; Accepted date: Aug 12, 2016

\section{Abstract}

$\mathrm{B}$ ACKGROUND: Alpinia galanga (A. galanga) was reported as a potential medicinal source due to its wide effect. A. galanga rhizome crude extract (ARCE) was reported to have high cytotoxic effect in cancer cells, but low in normal cells. However half maximal inhibitory concentration $\left(\mathrm{IC}_{50}\right)$ of ARCE is not clearly known yet. Hence, current study was conducted to investigate the $\mathrm{IC}_{50}$ of ARCE in normal standard fibroblast cell line, NIH-3T3 cells.

METHODS: Rhizomes of A. galanga were collected, peeled, dried, milled and weighed. Extraction was performed using maceration method, then filtered and evaporated. ARCE with various concentrations were applied in NIH-3T3 cells for 24 or 48 hours. Cells were documented and counted with 3-(4,5-dimethylthiazol-2-yl)-2,5-Diphenyltetrazolium bromide (MTT) assay.
RESULTS: Five hundreds grams of simplicia were macerated with ethanol and evaporated, $1 \mathrm{mg} / \mathrm{mL}$ crude extract with total volume of $114 \mathrm{~mL}$ was obtained. By addition of ARCE in NIH-3T3 cell culture, number of NIH-3T3 cells were shown less when treated with higher concentration of ARCE. Cell numbers of 0, 3.125, 6.25, $12.5,25$ and $50 \%$ ARCE treatment for 24 hours are $11,531,11,352,10,920,10,365,9,471,8,360$, respectively, meanwhile for 48 hours are $13,219,12,686,12,278,11,390$, $10,279,8,390$, respectively.

CONCLUSION: $\mathrm{IC}_{50}$ of ARCE in 24 hours treatment was $620.5 \mu \mathrm{g} / \mathrm{mL}$, while in 48 hours treatment was $666.6 \mu \mathrm{g} /$ $\mathrm{mL}$. Hence, ARCE is suggested to have low cytotoxic effect in NIH-3T3 cells.

KEYWORDS: Alpinia galanga, ginger, extract, cytotoxic, MTT, NIH-3T3

Indones Biomed J. 2017; 9(1): 23-8

\section{Introduction}

Plants have been used as one of the most important sources for medicines. Indonesia with its wide biodiversities has plenty of resourceful natural materials those should be explored. Previously our team reported several potential extracts derived from plants including Ipomea batatas (1-3), Artocarpus altilis (4), Piper crocatum (5), Kleinhovia hospita (6), Artocarpus heterophyllus (7), Catharanthus roseus (8), Piper betle (9), Catharanthus roseus (9), Dendrophtoe petandra (9), Curcuma mangga(9), Curcuma longa (10), Ananas comosus(11), Brucea javanica $(12,13)$, Nephelium lappaceum (14), Cucumis melo (15,16), Caesalpinia sappan (17) and Artocarpus elasticus (18). These extracts shows various activities, including osteoclastogenesis inhibition (1-3), apoptosis induction or proliferation 
inhibition on breast cancer cells (4,5,7-9), antioxidant $(6,14,16,18)$, proliferation and differentiation induction on stem cell $(10,15)$, and apoptosis induction on human oral squamous cell carcinoma $(12,13,16,17)$.

In addition, Alpinia galanga (A. galanga) was reported as a potential medicinal source due to its wide effect as anti-inflammatory, analgesic, anti-cancer, anti-melanogenic, hepato-protective, anti-microbial and anti-fungal agent.(19) In neuroprotective report against alzheimer disease, A. galanga was suggested to play the neuroprotective effect on Met-Leu-Gly-Ile-Ile-Ala-Gly-LysAsn-Ser-Gly Amyloid- $\beta(A \beta)$-induced amnesia in mice via the increment in $\mathrm{Na}^{+}, \mathrm{K}^{+}$-adenosine triphosphate (ATP)-ase, the improvement of antioxidant activity and the decrease of acetylcholinesterase level to improve the cognition by enhancing cholinergic transmission.(20) A. galanga was reported to contain, among other components, essential oils, tannins, phenol, glycosides, monoterpenes, carbohydrates, gallic acid, galangoisoflavonoid, $\beta$-sitosterol, galangin, alpinin, zerumbone, kampferide, pinocembrin, hydroxycinnamaldehyde (HCA) and acetoxychavicol acetate.(19,21-23) It is mostly cultivated in Egypt, India, Indonesia, Malaysia, Saudi Arabia, Sri Lanka and Thailand.(19)

It has been reported that 4'-HCA isolated from A. galanga was cytotoxic to human leukemic HL60 and U937 cell lines in a dose-dependent manner.(19,22) Meanwhile in normal cell, A. galanga rhizome crude extract (ARCE) at a dose of $100 \mu \mathrm{g} / \mathrm{mL}$ caused $15 \%$ apoptosis of MCF-12A cells, a normal epithelial cell derived from breast in 24 hours treatment, and at a dose of $1,000 \mu \mathrm{g} / \mathrm{mL}$ caused $5 \%$ apoptosis of CRL2522 cells, a normal fibroblast cell, in 24 hours treatment.(24) Therefore, half maximal inhibitory concentration concentration $\left(\mathrm{IC}_{50}\right)$ of $\mathrm{ARCE}$ is not clearly known yet. Hence, current study was conducted to investigate the $\mathrm{IC}_{50}$ of ARCE in normal standard fibroblast cell line, NIH-3T3 cells.

\section{Methods}

\section{Extraction of $A$. galanga Rhizome}

Rhizomes of A. galanga were collected, peeled, dried at $40^{\circ} \mathrm{C}$ for 3 days, milled and weighed. Extraction was performed using maceration method with $70 \%$ ethanol solvent in ratio of $1: 10$ for 5 days at $4{ }^{\circ} \mathrm{C}$. The solvent was added gradually, then filtered and evaporated with a rotary evaporator (Buchi Rotavapor R-124, Buchi, Flawil, Switzerland) at $40^{\circ} \mathrm{C}$. Maceration results were stored in a refrigerator at $4^{\circ} \mathrm{C}$.

\section{NIH-3T3 Cell Culture}

NIH-3T3 cells, a cell line derived from desegregated NIH Swiss mouse embryo fibroblasts which has become a standard fibroblast cell line (25), were cultured using Dulbecco's Modified Eagle Medium containing 10\% fetal bovine serum (FBS), penicillin, streptomycin, and amphotericin $\mathrm{B}$ in a humidified, $37^{\circ} \mathrm{C}, 5 \% \mathrm{CO}_{2}$ incubator. Upon reaching $80 \%$ confluency, cells were subcultured and propagated.

\section{Cytotoxic Test}

Cytotoxic test was performed using 3-(4,5-dimethylthiazol2-yl)-2,5-Diphenyltetrazolium bromide (MTT) assay (Sigma). The MTT assay provides a quantitative measurement of viable cells by determining the amount of formazan crystals produced by metabolically active cells. Briefly, $1 \times 10^{4}$ cells were seeded into each well of 96-well plates in medium containing active agent, 1:1,000 diluted hydrogen peroxide or medium merely. Cells were incubated for 24 or 48 hours. Ten $\mu \mathrm{l}$ of $5 \mathrm{mg} / \mathrm{mL}$ MTT in phosphate buffer saline (PBS) was added to each well. The plate was then incubated for 4 hours, and then the medium was discarded and formazan crystals were dissolved in 100 $\mu \mathrm{L}$ of $0.1 \mathrm{~N} \mathrm{HCl}$. The absorbance of cells was measured at $570 \mathrm{~nm}$ by a microplate reader. Untreated cells were counted with a hemacytometer and used for interpolating the absorbance.

\section{Results}

\section{ARCE Production}

Eight kilograms of A. galanga rhizome were collected. After skin peeling and drying, $1 \mathrm{~kg}$ of simplicia was obtained. Five hundreds grams of simplicia were macerated with ethanol and evaporated, $1 \mathrm{mg} / \mathrm{mL}$ crude extract with total volume of $114 \mathrm{~mL}$ was obtained.

\section{Effect of ARCE on NIH-3T3 Cell}

Results showed that by addition of ARCE in NIH-3T3 cell culture, number of NIH-3T3 cells were shown less when treated with higher concentration of ARCE (Figure 1). After MTT assay, absorbances were correlated with cell densities 
A

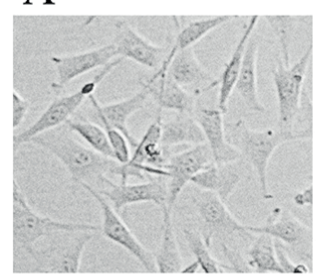

D

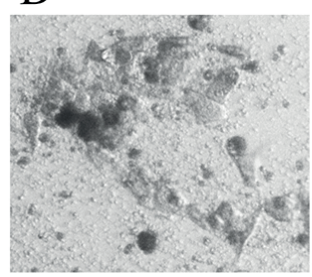

G

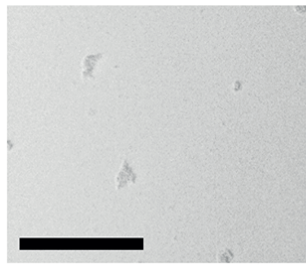

B

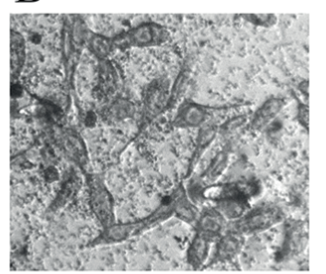

E

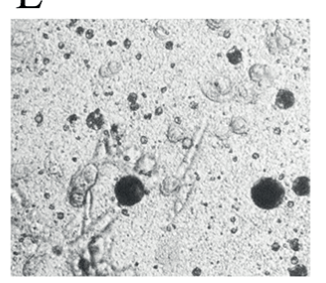

$\mathrm{H}$

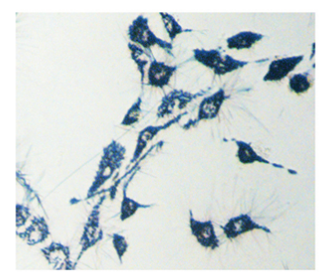

$\mathrm{C}$

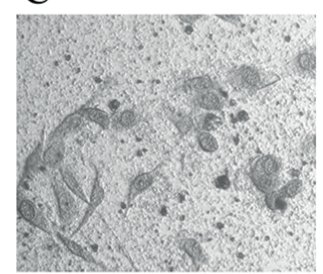

$\mathrm{F}$

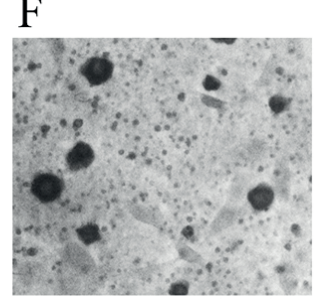

Figure 1. Expression of ARCE-treated NIH-3T3 cells. NIH-3T3 cells were seeded into 96-well plates. NIH-3T3 cells were treated with 0 (A), $3.125(\mathrm{~B}), \quad 6.25(\mathrm{C}), \quad 12.5(\mathrm{D}), 25(\mathrm{E})$ and $50 \%(\mathrm{~F})$ ARCE in DMEM containing 2\% FBS for 48 hours. Cells were documented with an inverted light microscope in the same magnification. (G): NIH-3T3 cells were treated with $\mathrm{H}_{2} \mathrm{O}_{2}$. (H): NIH-3T3 cells were incorporated with MTT, formazan crystals were formed in cells. Black bar: $50 \mu \mathrm{m}$.

for 24 hours $(\mathrm{y}=0.0623 \mathrm{x}+0.0065)$ (Figure $2 \mathrm{~A})$ and 48 hours $(y=0.0595 x+0.0114)$ (Figure $3 \mathrm{~A})$ treatments, cell numbers were gained after interpolation. Highest cell numbers was observed in $0 \%$ ARCE, followed by $3.125 \%$ ARCE, $6.25 \%$ ARCE, $12.5 \%$ ARCE, 25\% ARCE and 50\% ARCE. By interpolating the cell number for 24 hours treatment, the number for the group treated with $0 \%$ ARCE was 11,531, while $3.125 \%$ ARCE was 11,$352 ; 6.25 \%$ ARCE was 10,$920 ; 12.5 \%$ ARCE was 10,$365 ; 25 \%$ ARCE was 9,471; 50\% ARCE was 8,360 (Figure 2B). Meanwhile, for cell number for 48 hours treatment, number for the group treated with $0 \%$ ARCE was 13,219 , while $3.125 \%$ ARCE was 12,686; 6.25\% ARCE was 12,278; $12.5 \%$ ARCE was 11,$390 ; 25 \%$ ARCE was 10,$279 ; 50 \%$ was 8,390 (Figure 3B).

\section{IC $_{50}$ of ARCE on NIH-3T3 Cells}

Based on calculation with formula of $y=-63.977 x+11366$, $y=$ half number of untreated cells $(1 / 2 \times 11,531)$ and $x=$ $\mathrm{IC}_{50}$, we found that 24-hours-treatment $\mathrm{IC}_{50}$ of ARCE was $87.54 \%$. This equaled to $62.05 \% \times 1 \mathrm{mg} / \mathrm{mL}=0.6205 \mathrm{mg} /$ $\mathrm{mL}$ or $620.5 \mu \mathrm{g} / \mathrm{mL}$. Meanwhile based on calculation with formula of $y=-94.325 x+12897, y=$ half number of untreated cells $(1 / 2 \times 13,219)$, we found that 48 -hours-incubation $\mathrm{IC}_{50}$ of ARCE was $66.66 \%$. This equaled to $66.66 \% \times 1 \mathrm{~g} / \mathrm{mL}=$ $0.6666 \mathrm{mg} / \mathrm{mL}$ or $666.6 \mu \mathrm{g} / \mathrm{mL}$.

\section{Discussion}

Based on our current results, we found that ARCE decreased viable NIH-3T3 cells in a dose dependent manner. The decrease of ARCE-induced viable NIH-3T3 cells could be found in both 24 and 48 hours treatments. Based on calculation, $\mathrm{IC}_{50}$ of ARCE in 24 hours treatment was 620.5 $\mu \mathrm{g} / \mathrm{mL}$, while in 48 hours treatment was $666.6 \mu \mathrm{g} / \mathrm{mL}$. These results suggested that ARCE cytotoxic effect was slightly impaired after 48 hours. Previous study in normal cell for 24 hours, $100 \mu \mathrm{g} / \mathrm{mL}$ ARCE was reported to induce $15 \%$ apoptosis of MCF-12A cells, and $1,000 \mu \mathrm{g} / \mathrm{mL}$ caused $5 \%$ apoptosis of CRL2522 cells.(24) In addition, treatment of $750 \mu \mathrm{g} / \mathrm{mL}$ ARCE on MRC-5 cells, a human fetal lung fibroblast cell line, for 48 hours, did not induce the cell into apoptosis.(26) Hence, ARCE showed low cytotoxic effect in normal fibroblasts, including MCF-12A, CRL2522, MRC-5 and NIH-3T3 cells.

Unlike in normal fibroblasts, $\mathrm{IC}_{50}$ of ARCE in cancer cells is relatively low. For example, $\mathrm{IC}_{50}$ of ARCE in COR-L23 cells, a lung cancer cell line, was 5.4-13.3 $\mu \mathrm{g}$ / $\mathrm{mL}$ and $\mathrm{IC}_{50}$ of ARCE in MCF7 cells, a breast cancer cell line, was 5.4-170 $\mu \mathrm{g} / \mathrm{mL}$. $(26,27)$ ARCE was also reported to induce apoptosis in PC-3 cells, a prostate cancer cell line, in concentration of $100 \mu \mathrm{g} / \mathrm{mL}, 69 \%$ of total tested PC-3 cells 
A

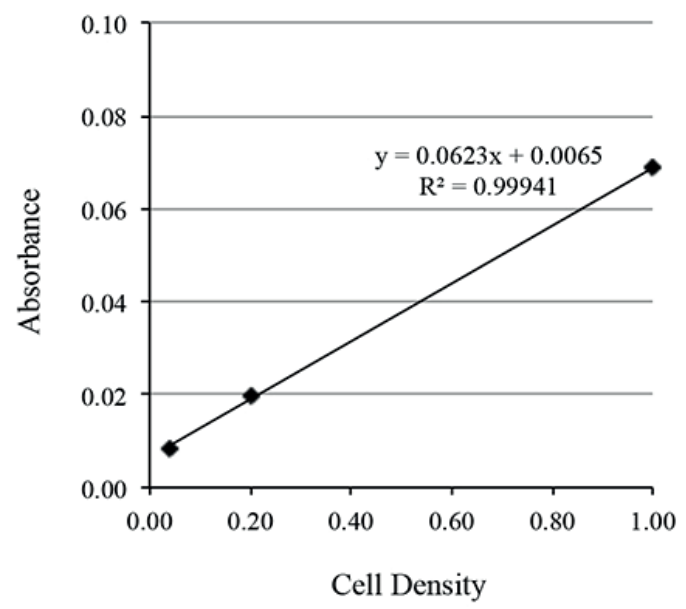

B

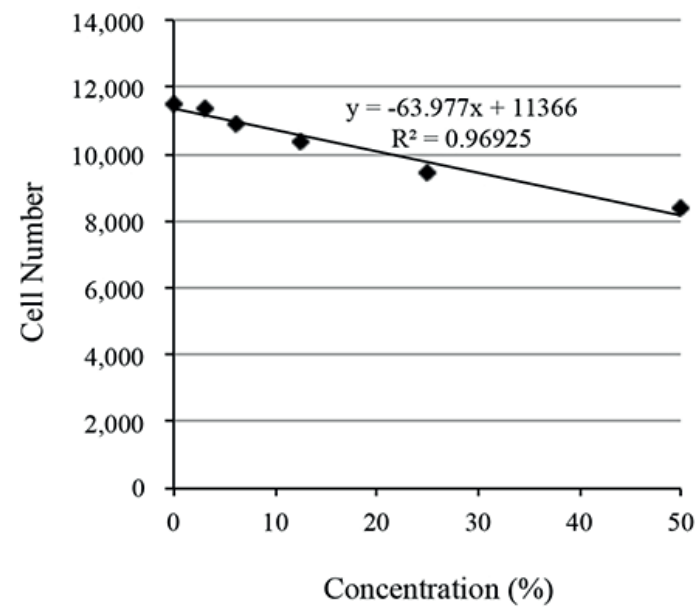

Figure 2. Effect of ARCE on viability of NIH-3T3 cells for $\mathbf{2 4}$ hours. Ten thousand NIH-3T3 cells were seeded into each well of 96-well plates. NIH-3T3 cells were treated with $0,3.125,6.25,12.5,25$ and 50\% ARCE in DMEM containing 2\% FBS for 24 hours. Cell viabilities were measured with MTT assay as described in Methods. A: Obtained absorbances were correlated with cell density (1.0 cell density equaled to 11,531 cells). B: Interpolated number of viable NIH-3T3 cells after treated with ARCE in various concentrations for 24 hours.

A

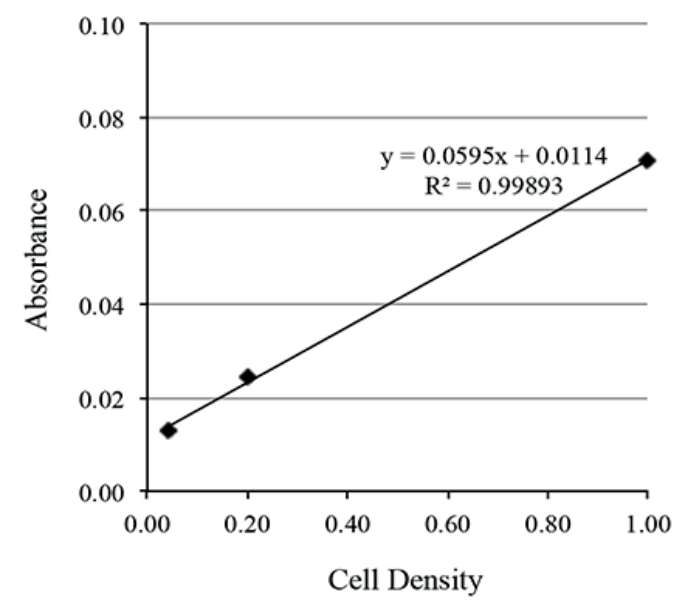

B

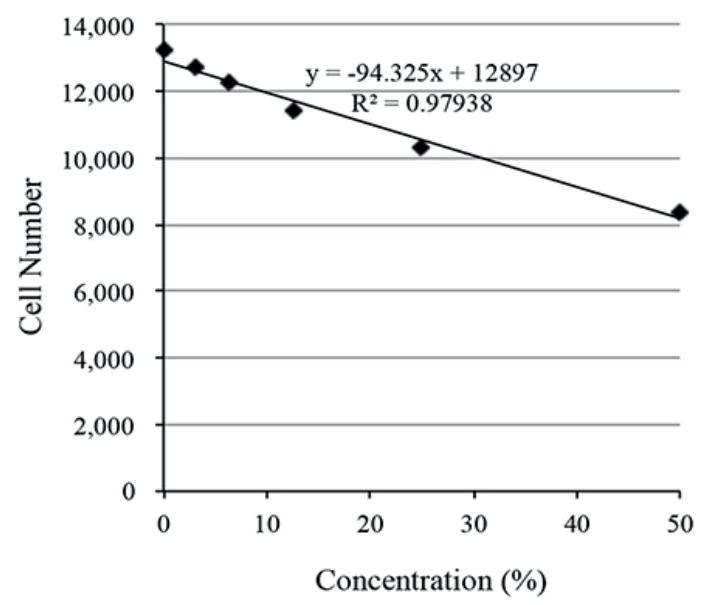

Figure 3. Effect of ARCE on viability of NIH-3T3 cells for 48 hours. Ten thousand NIH-3T3 cells were seeded into each well of 96-well plates. NIH-3T3 cells were treated with $0,3.125,6.25,12.5,25$ and 50\% ARCE in DMEM containing 2\% FBS for 48 hours. Cell viabilities were measured with MTT assay as described in Methods. A: Obtained absorbances were correlated with cell density (1.0 cell density equaled to 13,219 cells). B: Interpolated number of viable NIH-3T3 cells after treated with ARCE in various concentrations for 48 hours.

were induced into apoptosis.(28) This suggested that ARCE has higher cytotoxic activity in cancer cells.

A. galanga was reported to contain, among other components, essential oils, tannins, phenol, glycosides, monoterpenes, carbohydrates, gallic acid, galangoisoflavonoid, $\beta$-sitosterol, galangin, alpinin, zerumbone, kampferide, pinocembrin, HCA and acetoxychavicol acetate.(19,21-23) Pinocembrin induced loss of mitochondrial membrane potential, followed by release of cytochrome $c$ and activation of caspase- 9 and -3 in HCT 116 cells, a colon cancer cell line.(21) The initial trigger for pinocembrin-induced mitochondrial apoptosis appears to be by the translocation of cytosolic Bax protein to mitochondria.(21) Similar to pinocembrin, another active 
component of $A$. galanga, 4'-HCA, induced apoptosis in HL-60 cells, a leukemic cell line and U937 cells, a lyphoma cell line through intrinsic apoptotic pathway.(22) The 4'-HCA was reported to induce apoptosis by increasing reactive oxygen species production lead to endoplasmic reticulum stress pathway.(22) Meanwhile in an animal model system, galangin, a component of A. galanga as well, has inhibited the tumor growth by $73.51 \% \pm 4.742$ in Ehrlich ascites carcinoma (EAC) cells-induced Swiss Albino mice with no evidences of mortality as compared to standard drug, 5-fluorouracil. A. galanga and its components could possibly selectively induce apoptosis in cancer cells, but not in normal cells.

\section{Conclusion}

$\mathrm{IC}_{50}$ of ARCE in 24 hours treatment was $620.5 \mu \mathrm{g} / \mathrm{mL}$, while in 48 hours treatment was $666.6 \mu \mathrm{g} / \mathrm{mL}$. Hence, ARCE is suggested to have low cytotoxic effect in NIH-3T3 cells.

\section{References}

1. Tang QY, Kukita T, Ushijima Y, Kukita A, Nagata K, Sandra F, et al. Regulation of osteoclastogenesis by Simon extracts composed of caffeic acid and related compounds: successful suppression of bone destruction accompanied with adjuvant-induced arthritis in rats. Histochem Cell Biol. 2006; 125: 215-25.

2. Sandra F, Kukita T, Tang QY, Iijima T. Caffeic acid inhibited NFkB activation of osteoclastogenesis signaling pathway. Indones Biomed J. 2011; 3: 216-22.

3. Sandra F, Kukita T, Muta T, Iijima T. Caffeic acid inhibited receptor activator of nuclear factor $\mathrm{\kappa B}$ ligand (RANKL)-tumor necrosis factor (TNF) $\alpha$-TNF receptor associated factor (TRAF) 6 induced osteoclastogenesis pathway. Indones Biomed J. 2013; 3: 173-8.

4. Arung ET, Wicaksono BD, Handoko A, Kusuma IW, Yulia D, Sandra F. Anti-cancer properties of diethylether extract of wood from sukun (Artocarpus altilis) in human breast cancer (T47D) cells. Trop J Pharm Res. 2009; 8: 317-24.

5. Wicaksono BD, Handoko A, Arung ET, Kusuma IW, Yulia D, Pancaputra AN, et al. Antiproliferative effect of methanol extract of Piper crocatum Ruiz \& Pav leaves on human breast (T47D) cells in-vitro. Trop J Pharm Res. 2009; 8: 345-52.

6. Arung ET, Kusuma IW, Purwatiningsih S, Roh SS, Yang CH, Jeon $\mathrm{S}$, et al. Antioxidant activity and cytotoxicity of the traditional Indonesian medicine tahongai (Kleinhovia hospita L.) extract. J Acupunct Meridian Stud. 2009; 2: 306-8.

7. Arung ET, Wicaksono BD, Handoko YA, Kusuma IW, Shimizu K, Yulia D, et al. Cytotoxic effect of artocarpin on T47D cells. J Nat Med. 2010; 64: 423-9.
8. Widowati W, Mozef T, Risdian C, Ratnawati H, Tjahyani S, Sandra F. Apoptosis and antioxidant activities of Catharanthus roseus [L] G.Don extract on breast cancer cell line. Indones J Cancer Chemoprevent. 2010; 1: 99-107.

9. Widowati W, Mozef T, Risdian C, Ratnawati H, Tjahjani S, Sandra F. The comparison of antioxidative and proliferation inhibitor properties of Piper betle L., Catharanthus roseus [L] G.Don, Dendrophtoe petandra L., Curcuma mangga Val. extracts on T47D cancer cell line. Int Res J Biochem Bioinform. 2011; 1: 22-8.

10. Widowati W, Sardjono CT, Wijaya L, Laksmitawati DR, Sandra F. Extract of Curcuma longa L. and (-)-Epigallo Catechin-3-Gallate enhanced proliferation of adipose tissue-derived mesenchymal stem cells (AD-MSCs) and differentiation of AD-MSCs into endothelial progenitor cells. J USA-China Med Sci. 2012; 9: 22-9.

11. Margaretta DM, Chow A, Dirgantara Y, Djamil MS, Sandra F. Macerated-pineapple core crude extract-derived bromelain has low cytotoxic effect in NIH-3T3 fibroblast. Indones Biomed J. 2015; 7 : 101-6.

12. Wicaksono BD, Tangkearung E, Sandra F. Brucea javanica leaf extract induced apoptosis in human oral squamous cell carcinoma (HSC2) cells by attenuation of mitochondrial membrane permeability. Indones Biomed J. 2015; 7: 107-10.

13. Rizal MI, Sandra F. Brucea javanica leaf extract activates caspase-9 and caspase- 3 of mitochondrial apoptotic pathway in human oral squamous cell carcinoma. Indones Biomed J. 2016; 8: 43-8.

14. Widowati W, Maesaroh, Fauziah N, Erawijantari PP, Sandra F. Free radical scavenging and $\alpha$ - $\beta$-glucosidase inhibitory activities of rambutan (Nephelium lappaceum L.) peel extract. Indones Biomed J. 2015; 7: 157-62.

15. Lizandi AO, Sardjono CT, Frisca, Widowati W, Gunanegara RF, Sandra F. GliSODin meningkatkan potensi sel punca. Cermin Dunia Kedokteran. 2010; 37: 107-10.

16. Widowati W, Widyanto RM, Laksmitawati DR, Erawijantari PP, Wijaya L, Sandra F. Phytochemical, free radical scavenging and cytotoxic assay of Cucumis melo L. extract and B-carotene. JOAAT. 2015; 2: 114-9.

17. Wicaksono BD, Arung ET, Sandra F. Aktivitas antikanker dari kayu secang. Cermin Dunia Kedokteran. 2008; 35: 133-7.

18. Arung ET, Wicaksono DB, Sandra F. Prenylated flavonoid sebagai senyawa anti kanker yang berpotensi. Cermin Dunia Kedokteran. 2009; 36: 20-2.

19. Kaushik D, Yadav J, Kaushik P, Sacher D, Rani R. Current pharmacological and phytochemical studies of the plant Alpinia galanga. Zhong Xi Yi Jie He Xue Bao. 2011; 9: 1061-5.

20. Zhang LN, Sun YJ, Pan S, Li JX, Qu YE, Li Y, et al. $\mathrm{Na}^{+}-\mathrm{K}^{+}$-ATPase, a potent neuroprotective modulator against Alzheimer disease. Fundam Clin Pharmacol. 2013; 27: 96-103.

21. Kumar MA, Nair M, Hema PS, Mohan J, Santhoshkumar TR Pinocembrin triggers Bax-dependent mitochondrial apoptosis in colon cancer cells. Mol Carcinog. 2007; 46: 231-41.

22. Banjerdpongchai R, Punyati P, Nakrob A, Pompimon W, Kongtawelert P. 4'-hydroxycinnamaldehyde from Alpinia galanga (Linn.) induces human leukemic cell apoptosis via mitochondrial and endoplasmic reticulum stress pathways. Asian Pac J Cancer Prev. 2011; 12: 593-8.

23. Ohnishi R, Matsui-Yuasa I, Deguchi Y, Yaku K, Tabuchi M, Munakata $\mathrm{H}$, et al. 1'-acetoxychavicol acetate inhibits adipogenesis in 3T3L1 adipocytes and in high fat-fed rats. Am J Chin Med. 2012; 40: 1189-204.

24. Muangnoi P, Lu M, Lee J, Thepouyporn A, Mirzayans R, Le XC, et al. Cytotoxicity, apoptosis and DNA damage induced by Alpinia galanga rhizome extract. Planta Med. 2007; 73: 748-54. 
25. NIH 3T3 Cell Line - mouse embryonic fibroblasts - General Information [Internet]. San Fransisco: NIH 3T3 Cell Line. [cited May 22, 2016]. Available from: http://www.nih3t3.com/.

26. Samarghandian S, Hadjzadeh MA, Afshari JT, Hosseini M. Antiproliferative activity and induction of apoptotic by ethanolic extract of Alpinia galanga rhizhome in human breast carcinoma cell line. BMC Complement Altern Med. 2014; 14: 192. doi: 10.1186/1472-6882-14-192.

27. Lee CC, Houghton P. Cytotoxicity of plants from Malaysia and
Thailand used traditionally to treat cancer. J Ethnopharmacol. 2005; 100: 237-43.

28. Suja S, Chinnaswamy P. Inhibition of in vitro cytotoxic effect evoked by Alpinia galanga and Alpinia officinarum on PC-3 cell line. Anc Sci Life. 2008; 27: 33-40.

29. Jaiswal JV, Wadegaonkar PA, Hajare SW. The bioflavonoid galangin suppresses the growth of ehrlich ascites carcinoma in Swiss albino mice: a molecular insight. Appl Biochem Biotechnol. 2012; 167: 1325-39. 